\title{
地下施設計画のための 地下水浸透流ボクセル解析
}

\author{
櫻井英行 1 ・白石知成 2 \\ 1正会員 工修 清水建設株式会社 技術研究所（广135-8530 東京都江東区越中島3-4-17） \\ 2正会員 工修 清水建設株式会社＼cjkstart技術研究所（广135-8530 東京都江東区越中島3-4-17）
}

\begin{abstract}
放射性廃棄物処分場などの地下施設の計画に役立つシステムを目標とし, ボクセル解析法による地下水 浸透流解析システムを開発した. 本論文では, 従来の有限要素法による地下水浸透流解析におけるメッシ 工作成の問題点を具体的に示すともに, ボクセル法による解析システムではそれらの問題点が解消され, 解析効率が大きく向上することを示す. また, ボクセル解析法の弱点である形状近似の不具合が, 解析精 度に及ぼす影響を検討した結果についても報告する.
\end{abstract}

Key Words : voxel, groundwater flow, geological structure, solid modeling, underground repository

\section{1. はじめに}

放射性廃棄物地層処分の地下施設1)等を計画する 上で, 候補地周辺の地下水流動場や地下施設建設に よる地下水流動場の変化を予測することは極めて重 要である2).この場合, 地質調查やFEM（Finite Element Method）に代表される数值解析に基づく検 討が行われると考えられるが, 信頼性の高い評価の ためには, 入念な調査と詳細な三次元解析が, 相互 に補完し合あうことが必要であろう。しかしながら, 実際には, 三次元水理地質モデルに対応するFEメッ シュ・モデルの作成が足かせとなり, 地質調查の進 展に解析が追従できないことや, 反対に効率的なメ ッシュ作成のために大胆な簡略化が行われるなどが 想定され, 両者の相互補完を十分に行うことは非常 に困難と言える.

機械設計の分野に目を向けると,ソリッド・モデ リング3)等による三次元形状モデラやFEMのプリ／ ポスト・プロセッサを備えた優れたCAE (Computer Aided Engineering）システムが開発されており, 商 用システムも多い。 また, 近年のハードウェア性能 の飛躍的な向上と低価格化により, 水準の高いCAE 環境を導入しやすくなっている.

このような優れたCAEシステムを利用できる環境 にあっても，三次元メッシュ作成には，製品の細部 までも忠実に表現した製品モデルから解析用形状モ デルへの簡略化や自動メッシュ生成アルゴリズムの

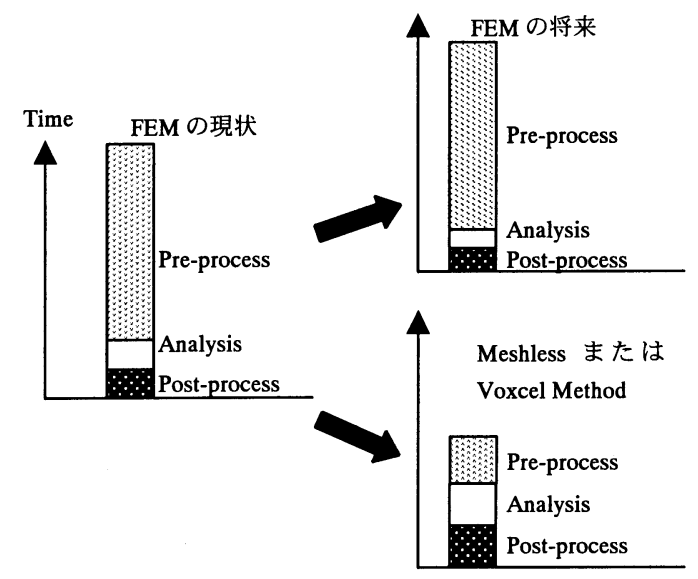

図-1 計算機の進歩に伴う解析時間の変化 ${ }^{4)}$

制約に起因する幾何形状の細分化といった，エンジ ニアの手作業に頼る部分が多く残されており, FEM 解析に要する時間は, 図-1に示すような状況にある というのが実状のようである ${ }^{4)}$. すなわち, FEM解 析においては, プリ・プロセスの手作業に要する時 間が大部分を占めているため, ハードウェアの進歩 によって, 解析やポスト・プロセス, プリ・プロセ スの一部（自動メッシュ生成処理）が, 時間短縮さ れても一連の解析プロセスのトータル時間はあまり 変わらないというものである.

本報告で対象としてる地質構造にはメッシュ分割 
を更に困難にしている決定的な要因がある．それは， 地質構造が複数の地層から構成されており, しかも, その地質境界（物性境界）が複雑に入り組んでいる ことである. 複合領域をメッシュ分割する場合, 隣 接する領域の境界面でメッシュ・パターンを一致さ せる必要があるが, それが幾何形状定義における手 作業を大幅に増やし, メッシュサイズの制御を難し くする. メッシュ生成法の研究は盛んに行われてい るが, この複合領域を対象とする研究例は少なく, 大きな課題として残されている ${ }^{5), 6)}$. すなわち, 三 次元地質構造を対象としたFEM解析は, 先に述べた 図-1の状況の典型であると言える.

こうした問題を根本的に解決しようとする新しい 解析手法としてメッシュレス法4),7)やボクセル解析 法出,8)が注目されている.これらは, プリ・プロセ スの手作業部分が解消される手法であれば, 反対に 解析時間やポスト・プロセス時間が増えることにな ったとしても, 解析のトータル時間は短縮されると いう発想から生まれた手法である. しかも, 時間が 增えた部分は, ハードウェアの進歩により自動的に 時間短縮されることが期待できる（図-1の下向き矢 印）。

メッシュレス法は, 要素情報を必要としない手法 であり, Smoothed Particle Hydrodynamics ${ }^{9}$ やPartition of Unity FEM ${ }^{10)}$ など，いくつかの方法があるが，内 挿関数にMLS（Moving Least Square）を用い, 連続 体解析に適用されたElement-free Galerkin Method ${ }^{11} に$ よって, 急速に研究・開発の動きが広まったと言え る.ところが, 適用例としは,クラックの進展問題 ${ }^{7), 12)}$ など, メッシュレスの利点を活かしてはいるも のの二次元問題の報告がほとんどであり, 三次元問 題に適用された報告 ${ }^{13), 14), 15)}$ はあっても, メッシュ作 成が困難な複合領域を対象とした報告は見あたらな い. 著者らも地下施設計画における三次元地下水解 析に対して強力な手法になりうることを検討してい るが, 二次元の例で構想を示したに過ぎない ${ }^{16)}$. メ ッシュレス法については, 三次元複合領域までも扱 える汎用的なシステムは, 開発されていないのが実 状であろう. 領域境界面の定義やMLSによる形状関 数作成のための高速な節点収集法等の他, 合理的な 全体システム設計も課題であると考えられる.

ボクセル解析法は, 三次元形状表現法の一種であ るボクセル・モデルを, そのまま, 解析用のメッシ ユ・モデルとして用いる方法（一般には, FEM）で ある. ボクセル・モデルでは, 三次元空間を非常に 小さな立方体, すなわちボクセル（Voxel：Volume Pixelの略）に分割し, 各ボクセルが対象物の内部と 外部のどちらに位置するのかを判定することによっ
て三次元形状を表現する. 形状が非常に複雑であっ ても, 確実, かつ, 高速にモデリングできるため, CTスキャナやMRIといった医療分野の画像処理等で 用いられてきた. 自由度数が非常に大きくなるため 解析要モデルとして用いられるようになったのは, 計算機資源の低価格化と高性能化が進んだ近年であ る. 節点座標が必要ないこと, 要素結合情報が少な くて済むこと, 要素形状が単一なので要素マトリッ クスをすべて記憶する必要がないことを考慮して, うまくプログラムすると, 大幅な記憶容量の削減が 可能になり, 数千万自由度といった通常のFEMより 格段に細かいメッシュによる解析が可能になる.

Hollister and Kikuchi ${ }^{17)}$ によって骨の微細構造の解析 に適用され，現在は，機械設計の分野でも実用化さ れ始めた ${ }^{18)}$. また, 幾何形状定義からボクセル・メ ッシュ生成, 境界条件設定, 解析, 結果表示までの 一連の処理を支援する商用CAEシステムが開発され るまでに至っている ${ }^{19), 20)}$. ボクセル解析法の短所は, 本来滑らかな境界面であっても階段状の形状近似と なり, 解析精度に影響する点である. ボクセル解析 法に関する研究報告には，この短所を改善を狙った ものも多( ${ }^{4), 8,, 18), 21), 22) . ~}$

以上のような状況の中, 著者らは, 地下施設計画 における浸透流解析の根本的な効率化を計ることを 目的として, ボクセル解析法を用いたCAEシステム を開発した.これは, 飽和浸透流解析機能, および, 地下施設計画に必要となる特別な機能を備えたシス テムである. 本論では, 従来型のFEMに代わり, ボ クセル解析法を用いることにより, 地下施設検討の ためのメッシュ作成が飛躍的に合理化されることを 述べるとともに, ボクセル法の弱点である境界面形 状近似の不具合が解析精度へ及ぼす影響について検 討した結果を報告する.

\section{2. 浸透流ボクセル解析システムの利点}

ソリッド・モデリングは, 多くのCAEシステムで 採用されている最も高度な三次元形状モデリング手 法の一つである，まず, FEMメッシュ作成のための ソリッド・モデリングにおける問題点を明らかにす るとともに, ボクセル解析を用いた場合には, それ らの問題点のほとんが解消され, さらには, より自 由度が高いモデリングが可能になることを述べる.

（1）地質構造のソリッド・モデリング

著者らは, 三次元地質構造を分かり易く表現する ことを目的として，それをりリッド・モデルとして 
作成し，画像化することの有効性を示した ${ }^{23)}$.

また，そのソリッド・モデルを合理的に定義・管 理する方法として, 地質構造を地層ブロック（地質 境界面や断層面で囲まれたソリッド・モデル）の集 合として扱い，各地層ブロックをそれを囲む曲面群 とそれらの論理演算式によって定義する方法を提案 した ${ }^{24), 25)}$.これは, ソリッド・モデリングの一手法 であるCSG（Constructive Solid Geometry） ${ }^{3)}$ の考え方 を踏襲したものであり, 地質境界面や断層面が曲面 補間プログラムによって具体化（instancing）される 基本要素（primitive）に対応付けられる. 著者らの 構築したシステムでは, 曲面補間は, ボーリング・ データや地質断面図等のデジタル・データから地質

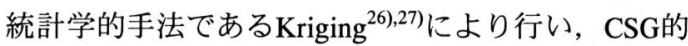
なデータに基づく最終的なソリッド・モデルとして の具現化と画像化は, 汎用のソリッド・モデラを用 いている.

ここで，図-2に示すような地質構造を例にとると, 前述のソリッド・モデリングでは, 図-3のように, 4つの地層ブロックに分けて構築することになる. ボクセル・メッシュの場合, 地質構造全体を包含す るボクセル空間を定義し, 各ボクセルがどの地層に 属するかを判定するだけなので, 図-3のソリッド・ モデルを使うことができるが, FEメッシュを作成し ようとする場合には，隣接する地層ブロックの境界 面を共有しないため，境界面上でメッシュの適合が 保証されないといった不都合が生じる，つまり，FE メッシュ用には, 通常, 図-4のように太線で表した 五つの面を共有するような単体のソリッド・モデル として作成する必要がある. 図-5に太枠で示した作 業がそれに対応するのであるが，著者らの経験では， 図-3のソリッド・モデル作成の倍以上の時間を要し, 地質構造が複雑になるほど，その倍率も大きくなる.

\section{（2）FEメッシュ作成のためのソリッド・モデリング}

図-4のようなソリッド・モデルを作成することが, 三次元浸透流解析を非効率にする最も大きな要因と なっているが, その具体的問題として以下の三つを 挙げることができる.

1) 図-4のソリッド・モデルの作成のための作業

（図-5の太枠）は，ほとんどが対話形式オペレー ションによる手作業とならざるを得ない，熟練才 ペレータでも, 機械的に手際よくモデリングする ことは難しい.

2) 地質境界面は起伏の激しい複雑な形状のため, 機 械部品の滑らかな曲面に比べて, 曲面同士の交差 曲線の計算が不安定になりやすい，その場合，著 者らの経験では，曲面形状を微妙に変えたり，曲

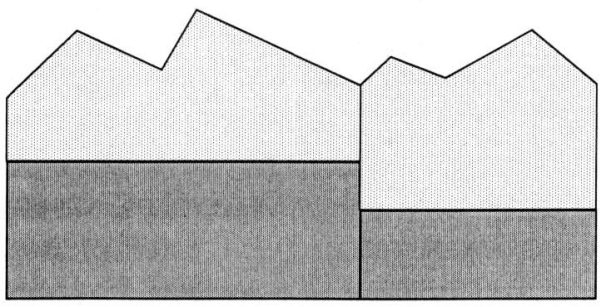

図-2 地質構造の例

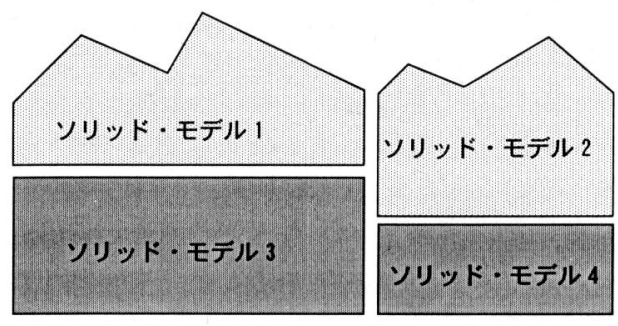

図-3＼cjkstart地質構造のソリッド・モデリング

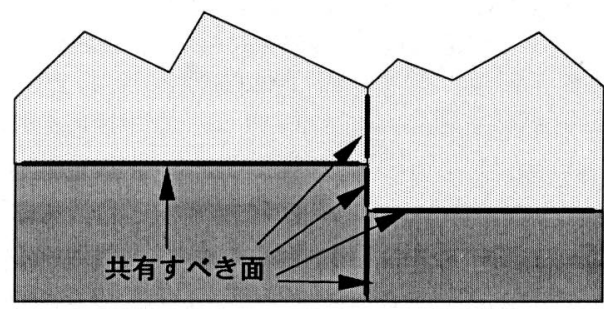

図-4 FEメッシュ用のソリッド・モデリング

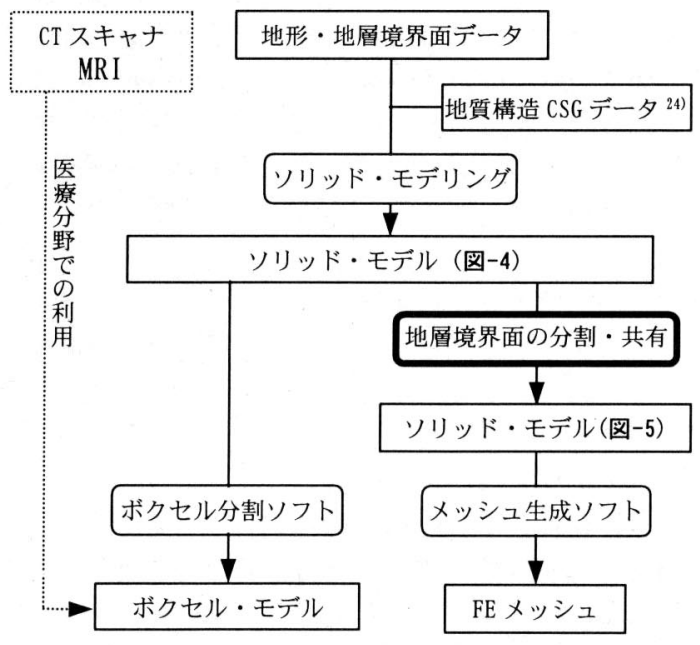

図-5 ボクセル・モデルとFEメッシュの作成 
面の位置を許容できる範囲内で移動したりといつ たノウハウを伴う対処が必要になる. 図-4のソリ ッド・モデルを作成するためには, 地層境界面を 共有するために更なる地層境界面の分割が必要に なり, この問題に遭遇する可能性が高くなる.

3) 図-6に示すように断層によって地質境界面が部分 的に不連続になるような曲面のモデリングは難し い. 断層を境にして二つの曲面に分けてモデリン グする方が扱いやすいが，FEメッシュ作成のため には, 連続な部分でエッジを完全に共有させる必 要がある.これは, 完全な手作業となる上, それ ぞれのソリッド・モデラに特有なノウハウも必要 とされるであろう.

\section{（3）ボクセル解析用のソリッド・モデリング}

ボクセル・メッシュ生成には, 図-3のようなりリ ッド・モデルを用いることができるが，このモデリ ングに対しては, 前述のCSG的なデータに基づき, 各地層ブロックを自動構築するためのプログラム （マクロ）を作り出すことができる. FEMの問題点 の2)で述べたように, 交差曲線の計算に失敗し, 人 間の判断を伴うような変更が生ずることがあるので, そのような変更までも含めて, 完全自動ですべての 地層ブロックを構築することは難しいが, FEMの1) で述べた手作業は必要ない. FEMの3)ついては, ボ クセル解析を前提にした場合は, 全く問題にならな い.このようにボクセル解析法を用いるとFEメッシ ユ作成のためのソリッド・モデリングの問題のほと んどが解消される.

ボクセル解析におけるメリットはこれだけではな く, 地質調査の進展に伴うメッシュの変更や地下施 設の位置検討のためのメッシュの変更も容易になる.

例えば, 図-7のように追加ボーリングによって, 新たな地層が発見され，それがレンズ状の地層であ ると解釈されたとする，その場合は，そのレンズ状 の地層ブロックを追加作成し, それに対応するボク セルの物性IDを変更するだけでよい.

地下施設も同様である. 別途作成した地下施設の ソリッド・モデルを所定の位置に配置した後, その 部分のボクセルの物性IDを変更することでモデル化 できるので, 施設位置の違いによる地下水流動場の 変化を比較することも容易である．このような地質 構造の変更や地下施設位置の検討を行う場合, 従来 のFEMでは, メッシュ作成が, 非常に手間のかかる 作業となることは明らかである。

以上, 解析メッシュをボクセル・モデルにすると いった割り切りを行うことにより，メッシュ作成効 率が格段に向上することを述べた. 著者らの経験で

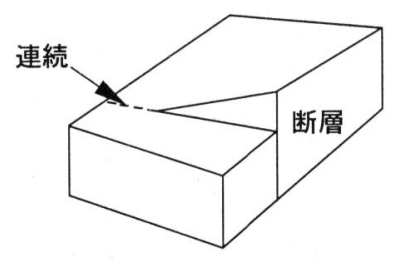

図-6 断層によって部分的に不連続になる地層

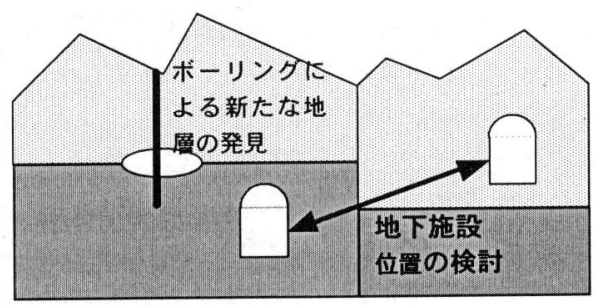

図-7 地質構造の修正と地下施設位置の検討

は, 従来型のFEメッシュ作成と比べ, 初期の幾何形 状定義（ソリッド・モデリング）では $1 / 3$ 以下, 地 質調査の進展に伴うメッシュの修正, 及び, 地下施 設の考慮とその位置変更では $1 / 10$ 以下の作業時間に なると見込んでいる. また, 計算時間については, 解析自由度が数百万から一千万程度であれば, ハイ エンド・ワークステーションで, 一晚で結果が得ら れる. 数時間の解析結果が一晚になったとしても, メッシュ作成の数週間が一週間程度に短縮されるこ とのメリットの方が大きいと考える.

次章では, ボクセル・モデルの形状近似と解析結 果の精度の関係について検討した結果を示す.

\section{3. 解析例と精度の検証}

ここでは, ダルシーの法則に従う多孔質媒体の流 れを扱い, 基礎方程式として次式を導入する.

$$
\begin{array}{cc}
\frac{\partial}{\partial x}\left(k_{x} \frac{\partial \phi}{\partial x}\right)+\frac{\partial}{\partial y}\left(k_{y} \frac{\partial \phi}{\partial y}\right)+\frac{\partial}{\partial z}\left(k_{z} \frac{\partial \phi}{\partial z}\right)=0 & \text { in } V(1) \\
\phi=\hat{\phi} & \text { on } S_{\phi}(2) \\
\partial \phi / \partial n=\hat{q} & \text { on } S_{n}(3)
\end{array}
$$

ここに，V， $S_{\phi}, S_{n}$ は，それぞれ解析領域と 2 種類 の境界条件が規定される解析領域境界面を表し， $\phi$ は全水頭, $k_{x}, k_{y}, k_{z}$ は透水係数, $\partial / \partial n$ は境界に立 てた法線方向微分である. この問題に対してガラー キン法を適用し，FEMにより離散化を行った．本来， 
ボクセルは立方体であるが，プログラム上は，ほと んど同じなので, ここでは，メッシュに柔軟性を持 たせるため, 次の長方形の形状関数を用いた.

$$
\begin{gathered}
\phi=\{N\}^{T}\{\phi\} \\
N_{i}=\frac{1}{a b c}\left(\frac{a}{2}+x x_{i}\right)\left(\frac{b}{2}+y y_{i}\right)\left(\frac{c}{2}+z z_{i}\right) \\
x_{i}=\left[\begin{array}{llllllll}
-1 & +1 & +1 & -1 & -1 & +1 & +1 & -1
\end{array}\right] \\
y_{i}=\left[\begin{array}{llllllll}
-1 & -1 & +1 & +1 & -1 & -1 & +1 & +1
\end{array}\right] \\
z_{i}=\left[\begin{array}{llllllll}
-1 & -1 & -1 & -1 & +1 & +1 & +1 & +1
\end{array}\right]
\end{gathered}
$$

ここで, $\{\phi\}$ は未知関数 $\phi$ の節点値, $\{N\}$ は形状関 数であり, 要素中心を原点として表した. $a, b, c$ は, それぞれ, 要素の $x, y, z$ 方向の大きさである. 要素内で透水係数は一定とすると, 最終的には式 (7)のような有限要素方程式が得られるが, 要素形状 が長方形なので式(8)(9)の積分は数値積分によらず, 陽な形で求めることができる. また, 要素形状が単 一なので, 各積分值と各地層の透水係数のみを記憶 しておくだけで, 式(7)への重ね合わせが可能となる.

$$
\left.\sum([K] \mid \phi\}-\{f\}\right)=0
$$

$$
\begin{gathered}
{[K]=k_{x} \int_{c} \int_{b} \int_{a}\left\{\frac{\partial N}{\partial x}\right\}\left\{\frac{\partial N}{\partial x}\right\}^{T} d x d y d z} \\
+k_{y} \int_{c} \int_{b} \int_{a}\left\{\frac{\partial N}{\partial y}\right\}\left\{\frac{\partial N}{\partial y}\right\}^{T} d x d y d z \\
+k_{z} \iint_{c} \int_{b}\left\{\frac{\partial N}{\partial z}\right\}\left\{\frac{\partial N}{\partial z}\right\}^{T} d x d y d z \\
\{f\}=\hat{q} \int_{S_{n}}\{N\} d s
\end{gathered}
$$

\section{（1）地下水面（地表面）のモデル化に関する検討}

飽和地下水浸透流解析では, 一般に, 地下水面が 既知であると仮定してモデル化される. つまり，モ デルの上面を地下水面に一致させて，そこに拘束条 件として大気圧を与えるため, 地下水面形状の近似 が解析精度に大きく影響する．ボクセル・モデルで は, 地下水面形状が階段状に近似されるため, モデ ル化には注意が必要である.

ここでは，図-8の一定勾配地下水面を有する二次 元場を対象とし，ボクセルの大きさと水面勾配 $i$ を 変化させた解析を行った. 境界条件は, 上面（地下

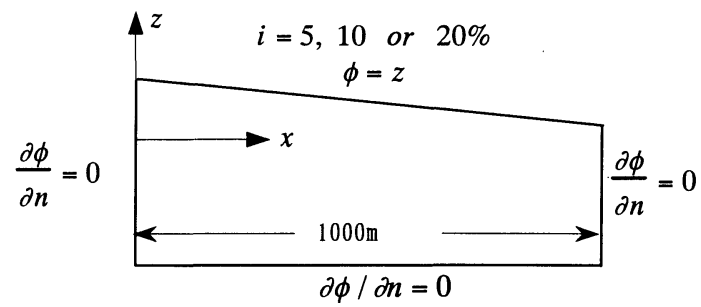

図-8 地下水面に関する検討のためのモデル

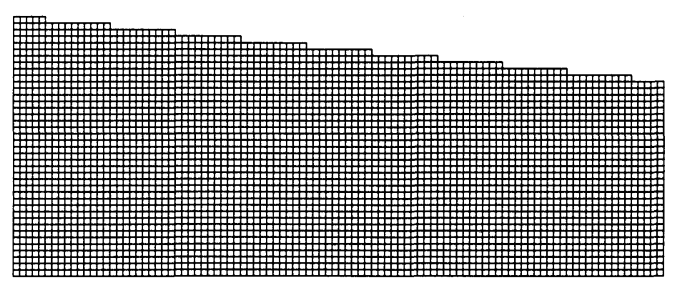

図-9＼cjkstart地下水面勾配が10\%のボクセル・メッシュ

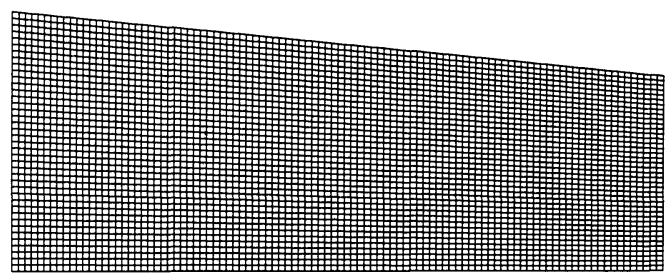

図-10 地下水面勾配が10\%のFEメッシュ

水面）で大気圧条件 $(p=0)$ の $\phi=z$ とし，その他の境 界は不透水条件である. 図-9及び図-10は，地下水 面勾配が10\%の場合のボクセル・メッシュ（ボクセ ル・サイズ10m） と比較のためFEメッシュである. ボクセル・モデルの地下水面は, 各ボクセルの中心 が地下水面以下に有るか否かで判定しているため, 階段状になる.

図-11から図-13は, 階段状の地下水面の節点にそ の節点の $z$ 座標值を拘束条件值として与え, $\phi=z_{\text {node }}$ とした場合の解析結果である. 図は, 全水 頭等值線を数本選んで描いたものであり, 細線が 図-10のFEメッシュ, 点線が5mボクセル・メッシュ, 太線は $10 \mathrm{~m}$ ボクセル・メッシュ, 淡い太線は $20 \mathrm{~m}$ ボ クセル・メッシュによる結果である. 各結果とも, ボクセルが小さくなるにつれて, 図-10のFEメッシ ユの結果に近づいており, ボクセルを細かくするこ とによる解の収束性は確認できる. ただし, 地下水 面形状が階段状になっている解への影響は, モデル の深部にも及んでおり, 無視できない. 


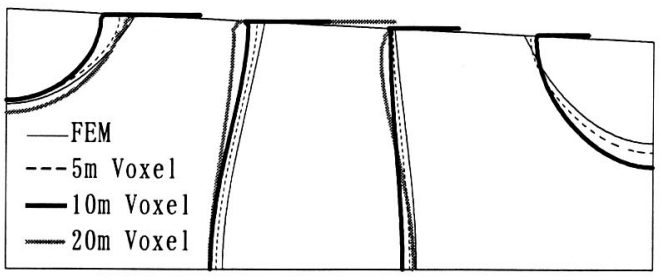

図-11 地下水面勾配が5\%の場合の結果比較

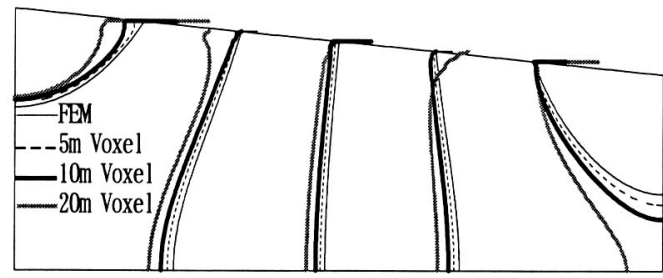

図-12 地下水面勾配が10\%の場合の結果比較

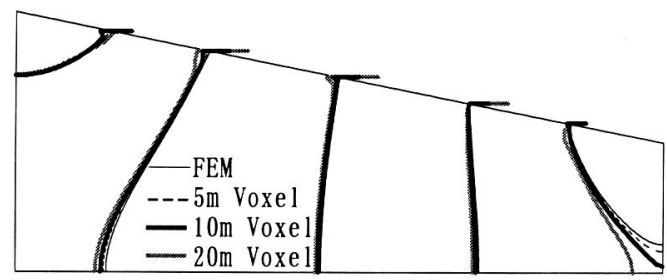

図-13 地下水面勾配が20\%の場合の結果比較

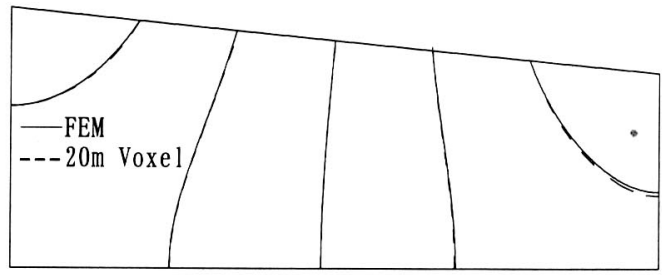

図-14 真の水面を境界条件とした場合の結果比較

ここで，もう一つの拘束条件設定方法による解析 結果を示す. それは, 階段状にモデル化された地下 水面上の節点にその節点の $z$ 座標値を与え, $\phi=z_{\text {node }}$ とするのではなく $x$ の関数として与えられる正し い地下水面の $z$ 座標值 $z_{\text {act }}(x)$ を与え, $\phi=z_{\text {act }}\left(x_{\text {node }}\right)$ とする方法である. 図-14は，この設定方法による 勾配が10\%の場合の解析結果である. 細線が図-10 のメッシュによるFEMの等值線, 破線が最も粗い 20mボクセルによる等值線である，両者は良好な一 致を示していることが分かる.

確認のため, 自然地形に適用した場合の解析も実 施した. 解析対象は, 東西 $17 \mathrm{~km} \times$ 南北 $17 \mathrm{~km} \times$ 深度 $5 \mathrm{~km}$ の領域である. 地下水面は, 地表面に一致する として, FEMメッシュおよびボクセル・メッシュを

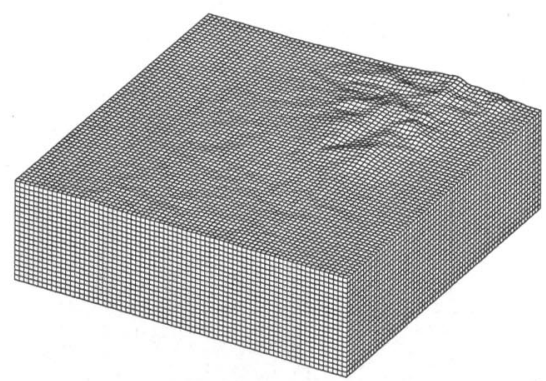

図-15 自然地形のFEメッシュ

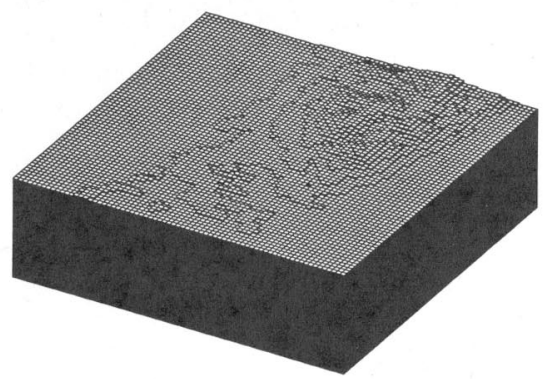

図-16＼cjkstart自然地形のボクセル・メッシュ

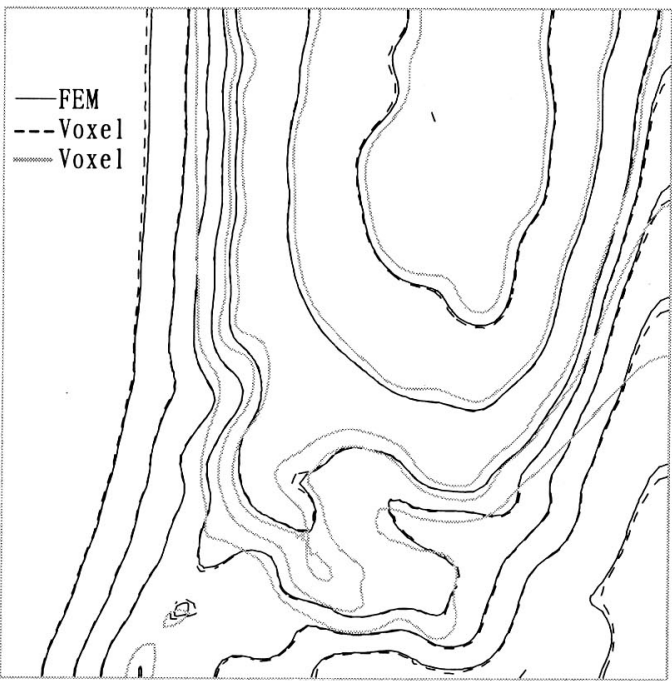

図-17 EL-500m水平断面における結果比較

作成した. 図-15に示すFEメッシュの要素サイズは, 約 $230 \mathrm{~m} \times 230 \mathrm{~m} \times 250 \mathrm{~m}$ であり, 要素総数は103,680で ある. 図-16のボクセル・メッシュのボクセル（こ こでは直方体）は約 $230 \mathrm{~m} \times 230 \mathrm{~m} \times 60 \mathrm{~m}$ であり，総 ボクセル数は440,631である. ボクセル・メッシュ では地形の近似精度に配慮して鈶直方向は細かく分 割している。境界条件は，地下水面上で大気圧 
（ $p=0 ）$ とし, その他の境界では不透水条件とした.

図-17に標高EL-500m水平断面での全水頭分布を 示す. 図中, 細線がFEMの解析結果である. 淡い太 線と破線は，それぞれボクセル・メッシュによる解 析結果であり, 前者が, 階段状にモデル化された地 下水面上の節点に対して, その節点の $z$ 座標值を拘 束条件とした場合, 後者は, 正しい地下水面の $z$ 座 標值を拘束条件とた結果である. 細線のFEMの結果 と破線のボクセルの結果はよく一致しているのに対 し, 淡い太線のボクセルの結果は大きく外れている 部分もある.なお，地形のモデル化には，国土地理 院の数值地図 $250 \mathrm{~m}$ メシュ標高の第1次地域区画メ ッシュ・コード6141（20万分の1地勢図の野辺地に 対応）を用いた。これは，第1次地域区画を日本列 島を北から南下するように眺めて, 解析領域を矩形 にした場合，側方の境界条件を設定しやすい領域を 含む区画として選んだものである.

以上のように，階段状にモデル化されるボクセ ル・メッシュの地下水面に対しては, 拘束条件とし て正しい地下水面標高値を与えることにより，比較 的粗いボクセル・メッシュを用いても精度良く解析 できることが確認できた.

\section{（2）地層境界面のモデル化に関する検討}

ボクセル・メッシュの地層境界面形状の近似精度 が解析結果に与える影響を検討するため, 図-18に 示すような3層構造のモデルを考え, 挟まれた地層 の透水係数 $k_{2}$ が隣接する地層の透水係数 $k_{1}$ と大きく 異なる場合の検討を行った．地層境界面は平面であ るが, 傾きがあるので, ボクセル・メッシュでは階 段状になり，結果に影響を及ぼすはずである．ここ では, 図-19の一辺が $20 \mathrm{~m}$ の場合（20,000ボクセル） と $5 \mathrm{~m}$ の場合（1,280,000ボクセル）の 2 通りのモデ ルを用意し，図-20を用いたFEM結果との比較を行 った。境界条件は，モデルの両端を全水頭拘束とし， その他の側面は不透水条件とした（図-18）.

図-21は $k_{2}=100 k_{1}$ の場合, 図-22は $k_{2}=1 / 100 k_{1}$ の場合 の解析結果である. 両図とも図-18に示す評価断面 での全水頭分布である. 図-21, 図-22において, 細 線は図-20のFEMの解析結果, 点線は, $5 \mathrm{~m}$ ボクセ ル・メッシュ, 淡い太線は $20 \mathrm{~m}$ ボクセル・メッシュ による解析結果である. また, 間隔の粗い破線は, 評価断面上での地層境界面である. ボクセル・サイ ズ $20 \mathrm{~m}$ の結果は, 地層境界面形状が階段状になる影 響を強く受けるため, その近傍で解が乱れているも のの，その他の部分では良好な結果が得られている. 一方, ボクセル・サイズ $5 \mathrm{~m}$ の結果は地層境界面近 傍でもFEMとよく一致している. 地層境界面の近似

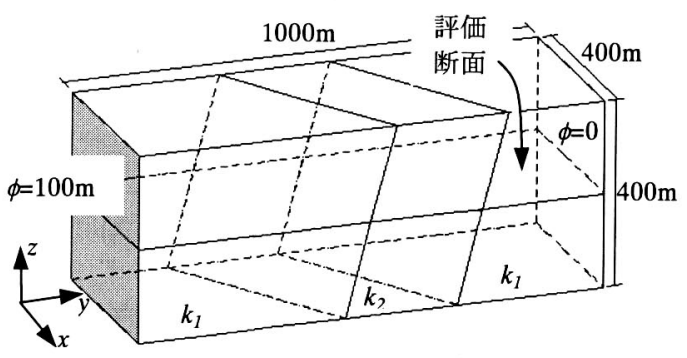

図-18 境界面近似の検討のための解析モデル

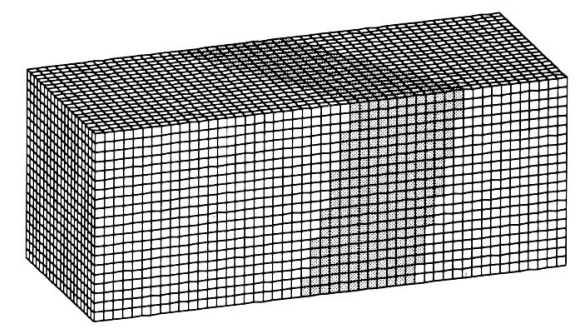

図-19３層構造のボクセル・メッシュ

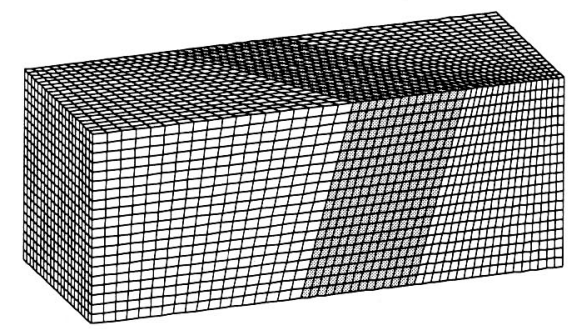

図-20 3層構造のFEメッシュ

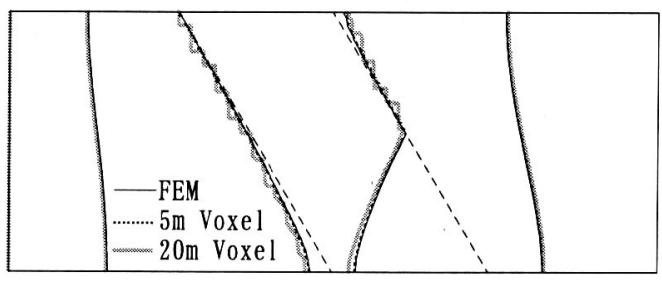

図-21 $k_{2}=100 k_{1}$ の場合の結果比較

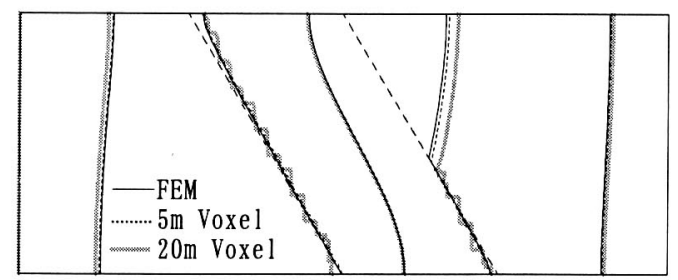

図-22 $k_{2}=1 / 100 k_{1}$ の場合の結果比較 
については, 地層境界面近傍で解が乱れるが, ボク セルが粗くても解全体への影響は小さいと言える. また，ボクセルを細かくすることによる境界付近の 解の収束性も良好である.

\section{（3）薄い地層のモデル化に関する検討}

ボクセル・メッシュでモデル化が難しい対象とし て断層破砕帯などの薄い地首がある. 例えば, $5 \mathrm{~km}$ $\times 5 \mathrm{~km} \times$ 深度 $2 \mathrm{~km}$ の領域をボクセル・メッシュ分割 することを考えると一辺が10mの立法体ボクセルで も5000万ボクセルにも達する. この場合, 幅が $10 \mathrm{~m}$ 以下の薄い地層のモデル化は難しくなる. 図-23は, $10 \mathrm{~m}$ のボクセルを用いて幅 $10 \mathrm{~m}$ と $6 \mathrm{~m}$ の地層をモデル 化した場合の不具合を示している. 各ボクセルの中 心位置で薄層の内外判定をした場合は, ボクセル・ サイズと同じ幅の地層をモデル化すると, 地層の連 続性は保持されるが隣接ボクセル間で部分的に面で の連続性が失われてしまう（図-23左, 濃くハッチ されたボクセル）。当然, ボクセル・サイズより薄 い地層の場合は, 地層の連続性が完全に失われるこ とになる（図-23右, 濃いハッチ）。また, ボクセ ルが部分的にでも対象の内側にあればよいことを判 定基準すると, 図-23の淡くハッチされたボクセル までが対象となり, 実際の地層より2倍以上に厚く なる部分も生じてしまう.

このような薄い地層を効率よくモデル化する手法 として, スメアードフラクチャーモデルがある ${ }^{28)}$. このモデルは, FEM解析において岩盤内に存在する 割れ目（薄層）を要素としてモデル化するのではな く, 見かけ上はモデル全体をすべて割れ目のない母 岩要素としてモデル化し, 母岩要素内に割れ目が存 在する場合には, その母岩要素の透水係数を母岩と 割れ目の断面積を用いて平均化する方法である.こ のモデルでは, 図-23に示した濃淡ハッチのすべて の要素の透水係数を一つ一つ平均化することになる. 三次元に分布する複雑形状の薄層の場合, 透水係数 の平均化は容易ではない.

ここでは, より簡略化したモデル化手法を提案す る.それは, 図-23の濃淡ハッチのように階段状に モデル化された薄層を一定幅の層に換算し, 式 (10)(11)で与えられる成層構造を成す地層の等価透 水係数を適用する方法である.

$$
\begin{aligned}
& k_{s}=\frac{\sum\left(t_{i} k_{i}\right)}{\sum t_{i}} \\
& k_{n}=\frac{\sum t_{i}}{\sum\left(t_{i} / k_{i}\right)}
\end{aligned}
$$

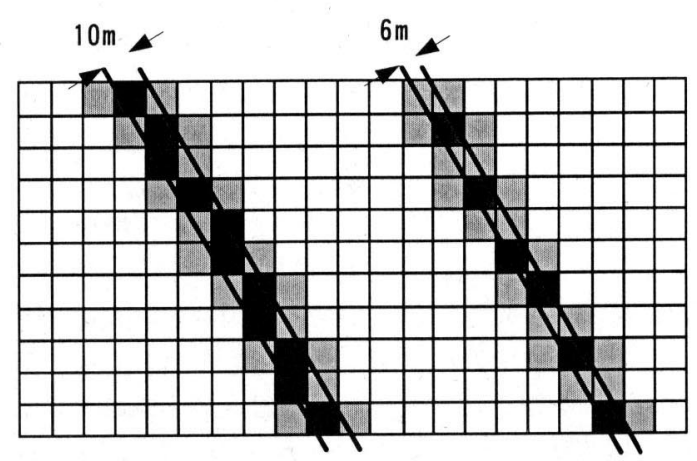

図-23薄い地層のモデル化における不具合
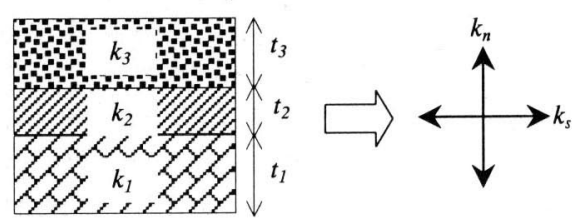

図-24成層構造を成す地層の等価透水係数

ここに, $k_{s}$ と $k_{n}$ は，図-24に示すような成層構造の 地層を単一層と見なした場合の層構造に沿う方向と それに直交する方向の等価透水係数である. $t_{i}$ は各 地層の厚さ, $k_{i}$ は各地層の透水係数である. ただし, 各地層は均質, 等方とする.

図-23の濃淡ハッチのボクセルの平均的な厚さ $t_{v}$ は, 薄層の厚さが概ね一定であるとすれば, ハッチのボ クセルの全体積を $V_{v}$, 薄層と母岩との境界面の面積 （片側のみ）を $A_{f}$ とすると次式で概算できる.

$$
t_{v}=V_{v} / A_{f}
$$

したがって, 厚さ $t_{v}$ の母岩の中に, 厚さ $t_{f}$ の薄層を 挟む三層構造と見なすことができるので, ハッチの ボクセルの等価透水係数は, 直交異方性の透水係数 として次式で近似できる.

$$
\begin{gathered}
k_{v s}=\frac{\left(t_{v}-t_{f}\right) k_{0}+t_{f} k_{f}}{t_{v}} \\
k_{v n}=\frac{t_{v}}{\left(t_{v}-t_{f}\right) / k_{0}+t_{f} / k_{f}}
\end{gathered}
$$

ここで, $t_{f}$ は, 薄層の真の（平均）厚さであり, $k_{0}$ と $k_{f}$ は, それぞれ母岩と薄層の透水係数である. $k_{v s}$ は薄層としてモデル化されたハッチのボクセルの 薄層に沿う方向の透水係数, $k_{v n}$ はそれに直交する方 
向の透水係数である. なお, ボクセルの体積 $V_{v}$ は濃 淡ハッチに対応するボクセルの個数から求めること ができるし, 薄層と母岩との境界面積 $A_{f}$ はソリッ ド・モデラが計算してくれるので式(13)(14)の等価 透水係数の計算は容易である.

この手法の妥当性を検討するため, 前節と同様に 図-25に示すような3層構造のモデルを考え, 厚さ $5 \mathrm{~m}$ の薄層の透水係数 $k_{f}$ が母岩の透水係数 $k_{0}$ と大きく 異なる場合の検討を行った. ボクセル・メッシュは, ボクセルの一辺が $20 \mathrm{~m}$ 場合（図-26, 20,000ボクセ ル）と $10 \mathrm{~m}$ 場合（160,000ボクセル）の 2 通りのモ デルを用意した．比較のためのFEメッシュでは, 図-27に示すように, 薄層を厚さ $5 \mathrm{~m}$ の要素で忠実に 分割した. 境界条件は, モデルの両端を全水頭拘束 とし，その他の側面は不透水条件とした（図-25）. 解析ケースの一覧を表-1に示す.

図-28は $k_{f}=100 k_{0}$ の場合の解析結果であり, 図-29 は $k_{f}=1 / 100 k_{0}$ の場合の解析結果である. 両図とも図25に示す評価断面での全水頭分布を示している.

図-28において, 三つの解析結果（Case1,2,3）は, よく一致しており, ここでの薄層のモデル化方法が 妥当であることが確認できる.

一方, 図-29の $k_{f}=1 / 100 k_{0}$ の場合の結果を見ると, 点線（Case5）と淡い太線（Case6）のボクセル・メ ッシュによる解析結果は, FEMの細線 (Case4) か ら大きく外れている.

ここで, 図-27のFEメッシュを用いて, 薄層の厚 さをあえて5倍程にモデル化し, 式(13)(14)の等価透 水係数を与えて解析を実施すると, 図-30の淡い太 線の結果 (Case7) が得られ, 細線のFEMの結果 （Case4）とよく一致していることが確認できる.

したがって, 式(13)(14)の等価透水係数によるモ デル化は妥当であって, 図-29のボクセル法による 結果とFEMの結果との差は, ボクセル・メッシュの 地層境界面が階段状になっていることによるものと 考えられる. 薄層の透水係数が母岩より小さい場合 は, 薄層に直交する方向に大きな動水勾配が発生し, 同方向の透水係数 $k_{v n}$ が支配的になる. ところが, ボ クセル・メッシュの場合は, 地層境界面が階段状に なるため xyz方向の各ボクセル面から薄層に流出入 することになり, 薄層に直交する透水係数 $k_{v n}$ だけで なく, 薄層に沿う方向の透水係数 $k_{v s}$ も流れ場に大き く寄与してしまう. ボクセル・メッシュの地層境界 面の面積は, ボクセルのサイズに依らず, 各座標軸 平面への投影面積となるため, この問題は, ボクセ ルを細かくしても改善される問題ではないと考えら れる. 図-31は, 薄層に沿う方向の透水性の影響を 排除するため, $k_{v s}$ のみをゼロとして解析した結果で
表-1 薄い地層に関する検討のための解析ケース

\begin{tabular}{|c|c|c|cc|cc|}
\hline Case & メッシュ & 薄層厚さ & $k_{0}$ & $k_{f}$ & $k_{v s}$ & $k_{v n}$ \\
\hline 1 & 任意六面体 $^{*}$ & $t_{f}=5 \mathrm{~m}$ & 1 & 100 & - & - \\
2 & $10 \mathrm{~m}$ Voxel $^{*}$ & $t_{v}=22.4 \mathrm{~m}$ & 1 & $\rightarrow$ & 23 & 1.3 \\
3 & 20 Voxel $^{*}$ & $t_{v}=33.2 \mathrm{~m}$ & 1 & $\rightarrow$ & 14 & 1.1 \\
\hline 4 & 任意六面体 $^{*}$ & $t_{f}=5 \mathrm{~m}$ & 1 & 0.01 & - & - \\
5 & $10 \mathrm{~m} \mathrm{Voxel}^{* *}$ & $t_{v}=22.4 \mathrm{~m}$ & 1 & $\rightarrow$ & 0.78 & 0.043 \\
6 & 20 Voxel $^{*}$ & $t_{v}=33.2 \mathrm{~m}$ & 1 & $\rightarrow$ & 0.87 & 0.073 \\
7 & 任意六面体 $^{*}$ & $t_{v}=23.2 \mathrm{~m}$ & 1 & $\rightarrow$ & 0.79 & 0.044 \\
\hline 8 & $10 \mathrm{~m} \mathrm{Voxel}^{* *}$ & $t_{v}=22.4 \mathrm{~m}$ & 1 & $\rightarrow$ & 0 & 0.043 \\
9 & 20 Voxel $^{*}$ & $t_{v}=33.2 \mathrm{~m}$ & 1 & $\rightarrow$ & 0 & 0.073 \\
\hline
\end{tabular}

*: 図-27, **: 図-26

$k: \mathrm{m} / \mathrm{sec}$

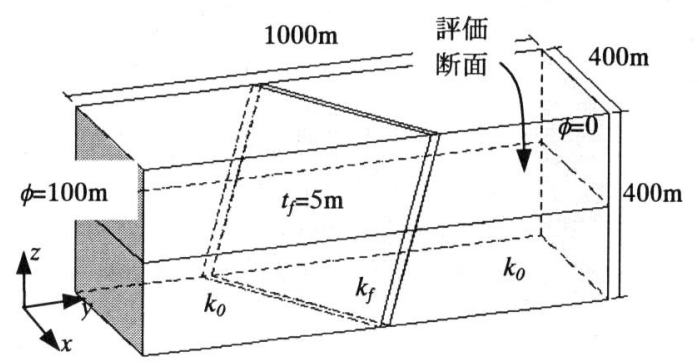

図-25 薄い地層に関する検討のための解析モデル

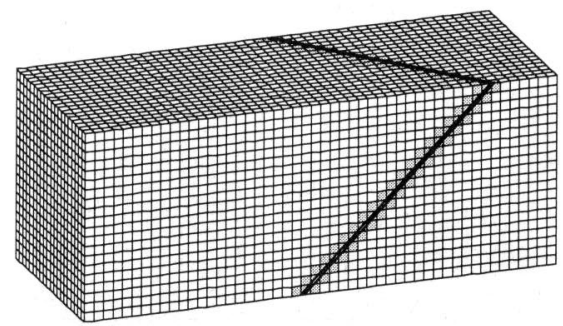

図-26 薄い地層を挟むボクセル・メッシュ

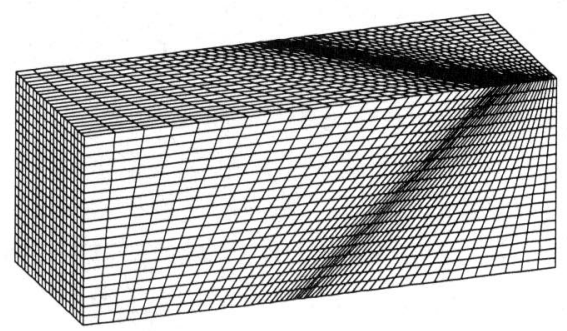

図-27薄い地層を含む任意六面体FEメッシュ

あるが，図-29に比べFEMに近い結果が得られてい ることが分かる. 薄層については, 薄層の透水性が 周りの母岩に比べて高いときは，ここで提案したモ デル化方法が妥当であると言えるが, 薄層の透水性 が低いときのモデル化方法は，検討の余地があると 思われる. 今後の課題としたい. 


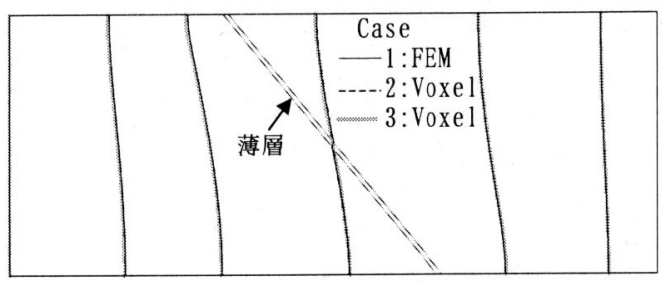

図-28 $k_{f}=100 k_{0}$ の場合の結果比較

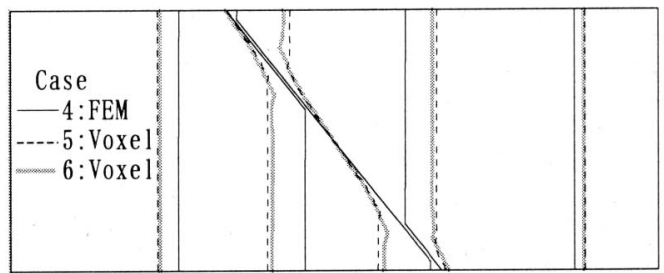

図-29 $k_{f}=1 / 100 k_{0}$ の場合の結果比較

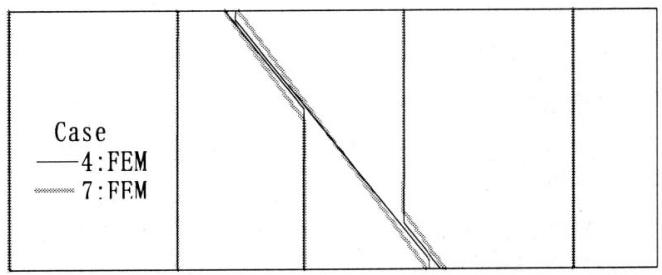

図-30 FEメッシュによる等価透水係数の確認

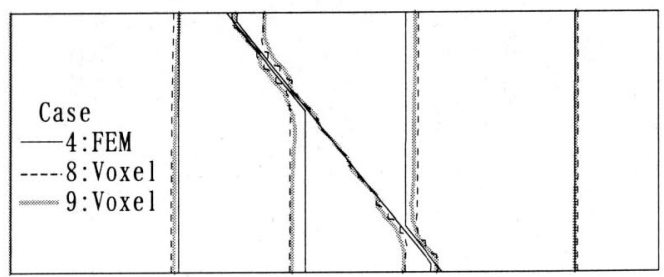

図-31 $k_{f}=1 / 100 k_{0}$ の場合の結果比較 $\left(k_{v s}=0\right)$

\section{（4）地下施設通過流量に関する検討}

ある地域に地下施設を計画する際に，その配置 （位置と向き）を検討する必要があるが, そのため の一つの指標として地下施設を通過する流量が挙げ られる. 特に, 廃棄物処分地下施設では, できるだ け通過流量が小さいことが望ましいであろう．以下， ボクセル・メッシュによる地下施設通過流量算出の 妥当性について検討した結果を示す.

モデルとしては, $400 \mathrm{~m} \times 400 \mathrm{~m} \times 1000 \mathrm{~m}$ の矩形領 域内に半径 $100 \mathrm{~m}$ の球体施設を考え, 施設の透水係 数が周りの地盤より大きい場合と小さい場合の検討 を行うこととした. 境界条件は, モデルの両端を全 水頭拘束とし, 強制的な動水勾配を与え, その他の 側面は不透水条件とした. 解析領域は対称性を考慮 して，1/4の領域とした（図-32）。ボクセル・メッ

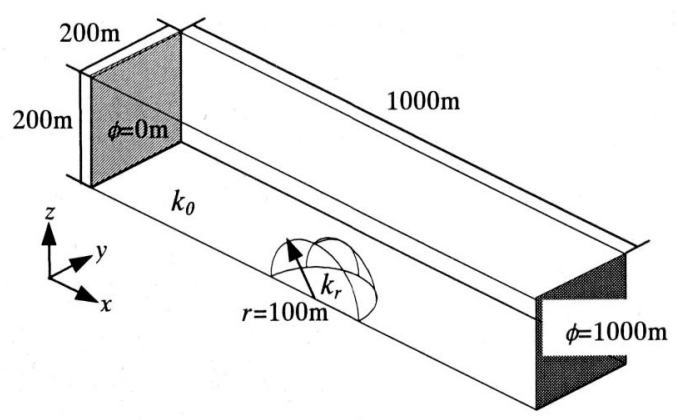

図-32 施設通過流量検討のための解析モデル

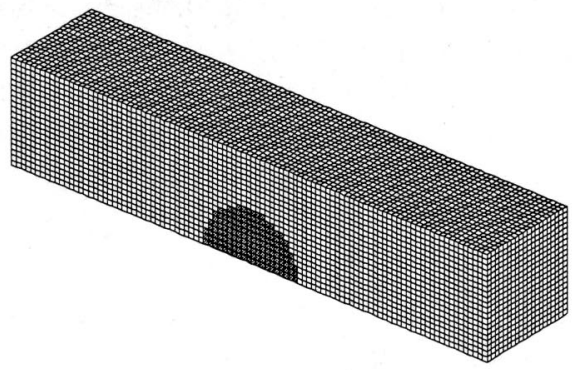

図-33 施設を含むボクセル・メッシュ

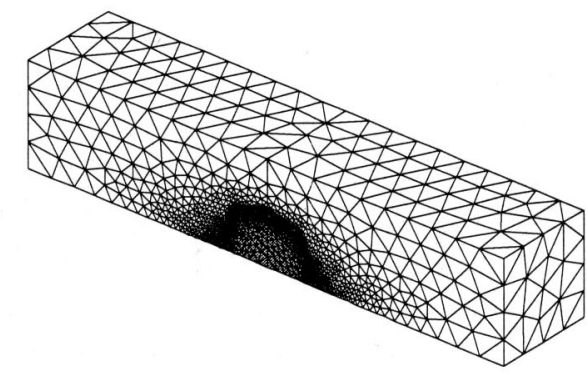

図-34＼cjkstart施設を含むFEメッシュ

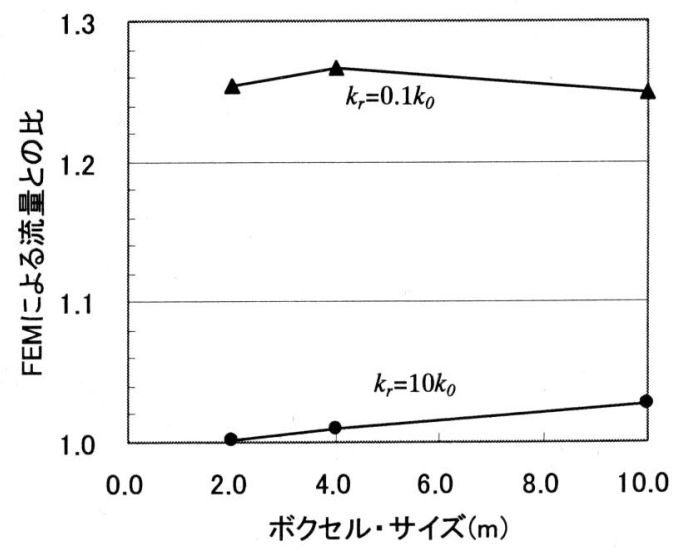

図-35 ボクセル・サイズと施設通過流量 

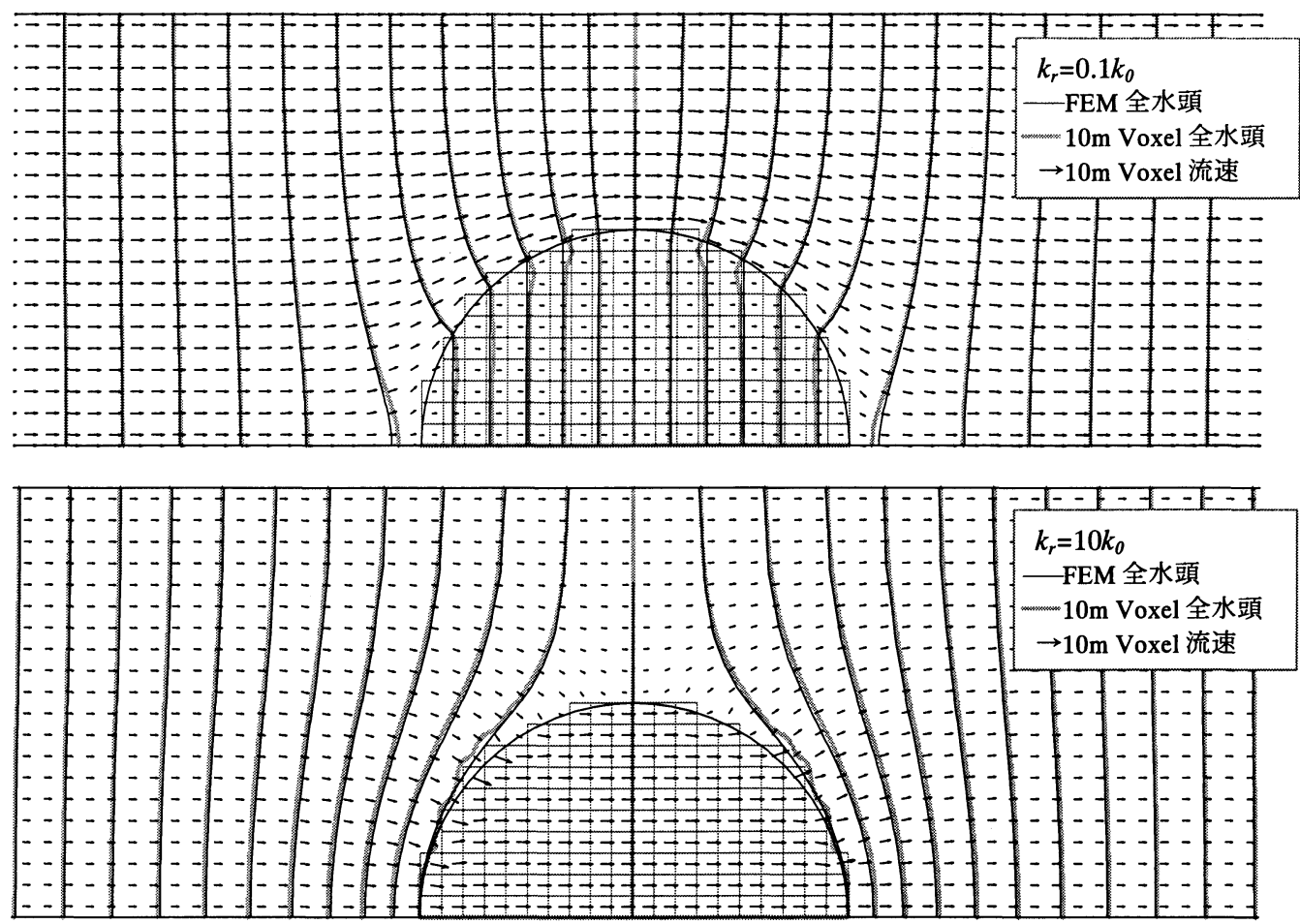

図-36 地下施設周辺の流れ場

表-2 地下施設通過流量の検討結果

\begin{tabular}{|c|c|c|c|c|c|c|c|c|c|c|}
\hline \multirow{2}{*}{ Model } & \multirow{2}{*}{ メッシュ } & \multirow{2}{*}{ 要素数 } & 施設体積 & & 施設表面積 & & $\begin{array}{c}\text { 流量 } \\
\left(k_{r}=10 \mathrm{~m} / \mathrm{sec}\right)\end{array}$ & & $\begin{array}{c}\text { 流量 } \\
\left(k_{r}=0.1 \mathrm{~m} / \mathrm{sec}\right)\end{array}$ & \\
\hline & & & $\left(\mathrm{m}^{3}\right)$ & 比率 & $\left(m^{2}\right)$ & 比率 & $\left(\mathrm{m}^{3} / \mathrm{sec}\right)$ & 比率 & $\left(\mathrm{m}^{3} / \mathrm{sec}\right)$ & 比率 \\
\hline 正解 & - & - & $1.047 \mathrm{E}+06$ & 1 & $3.142 \mathrm{E}+04$ & 1 & - & - & - & - \\
\hline 1 & 任意四面体 & 87,070 & $1.046 \mathrm{E}+06$ & 0.999 & $3.142 \mathrm{E}+04$ & 1.000 & 1.879 & 1 & 0.115 & 1 \\
\hline 2 & $10 \mathrm{~m}$ Voxel ${ }^{* *}$ & 40,000 & $1.056 \mathrm{E}+06$ & 1.008 & $4.740 \mathrm{E}+04$ & 1.509 & 1.931 & 1.028 & 0.143 & 1.248 \\
\hline 3 & 4m Voxel & 625,000 & $1.052 \mathrm{E}+06$ & 1.005 & $4.742 \mathrm{E}+04$ & 1.509 & 1.898 & 1.010 & 0.145 & 1.266 \\
\hline 4 & $2 \mathrm{~m}$ Voxel & $5,000,000$ & $1.048 \mathrm{E}+06$ & 1.001 & $4.716 \mathrm{E}+04$ & 1.501 & 1.881 & 1.001 & 0.144 & 1.254 \\
\hline
\end{tabular}

*: 図-34, **: 図-33

シュは, ボクセルの一辺が $10 \mathrm{~m}$ (図-33, 40,000ボク セル），4m（625,000ボクセル），2m（5,000,000ボ クセル）の3通りのモデルを用意した．比較のため のFEメッシュは, 図-34に示すように球体形状の近 似精度に配虑し, 四面体要素で分割した.

図-36に解析結果を示す，上の図は，地下施設の 透水性 $k_{r}$ が岩盤の透水性 $k_{0}$ に比べて小さい場合, 下 の図は, 地下施設の透水性が大きい場合である. 細 い等値線はFEMの全水頭分布, 太いの等值線は $10 \mathrm{~m}$ ボクセルによる全水頭分布, 矢線は $10 \mathrm{~m}$ ボクセルに よる流速ベクトルであり, 格子は, $10 \mathrm{~m}$ ボクセルに
よる施設のメッシュである. 両図とも全水頭分布に ついてはFEMとボクセルの結果は良好な一致を示し ていることが確認できる.

施設の通過流量 $Q_{r}$ は, 施設のメッシュのみで構成 される有限要素方程式により算出した. すなわち,

$$
\left\{q_{r}\right\}=\left[K_{r}\right]\left\{\phi_{r}\right\}
$$

ここで, $\left\{q_{r}\right\}$ は地下施設部分の反力に対応する節 点フラックスであり, 正負それぞれの総和が, 施設 への流入量, 流出量に対応し, それらは釣り合う. $\left[K_{r}\right]$ は施設の要素（ボクセル）のみで構成される係 
数マトリックス, $\left\{\phi_{r}\right\}$ は施設部分の解析結果の全水 頭節点值である.

図-35は，横軸にボクセル大きさをとり，縦軸は 式(15)で計算される施設通過流量をFEMの解析結果 との比で表したグラフである. 地下施設の透水性が 周辺地盤より大きい場合は, 地下施設通過流量が精 度よく計算されており，ボクセルの細分化に伴う収 束性も良好である. ところが，反対に地下施設の透 水性が周辺地盤より小さい場合は, FEMより $20 \%$ 以 上も大きい計算值となっている，しかも，ボクセル の細分化に伴う一定の収束性も認められない，施設 の透水性が低い場合には, 施設近傍は施設に沿って 流れる場となり，ボクセル・メッシュによる施設表 面の凹凸による細かな出入り加算しているためと考 えられる（図-35の上を参照）。表-2を見ると，地 下施設の体積の近似は, もっとも粗い $10 \mathrm{~m}$ ボクセル の場合も $0.8 \%$ の誤差であり十分細かいと言えるが, 表面積は, ボクセル・メッシュでは, 3 方向の座標 軸平面へ投影面積となるため, 球の場合, 真の表面 積の1.5倍に収束する。この表面積の近似も施設通 過流量の計算に関係しており, 施設の透水性が低い 場合には, ボクセルを細かくすることによる式(15) の施設通過流量の精度向上は, 現実的に期待できな いと言える.

ただし, 地下施設の配置による通過流量を比較す る上では，同じ物差しでの相対的な検討ができるの で, 先に述べたようにメッシュ作成が簡単なボクセ ル解析法は強力なツールになるであろう。

\section{4. おわりに}

地下施設計画における浸透流解析の根本的な効率 化を計ることを目的として, ボクセル解析法を用い たCAEシステムを開発した. 本論では, 通常のFEM ではなく, ボクセル解析法を用いることにより, 地 下施設検討のためのメッシュ作成が飛躍的に合理化 されることを具体的に示した. また，ボクセル法の 弱点である境界面形状近似の不具合が解析精度へ及 ぼす影響について検討し, 次のような結論を得た。

（1）地下水面を既知とする飽和解析では，地下水面 形状が階段状になっても, 拘束条件として, 真の 全水頭值を与えることにより精度よく計算できる. （2）地層境界面の近似については，地層境界面近傍 で解が乱れるが, ボクセルが粗くても解全体への 影響は小さい. また, ボクセルを細かくすること による境界付近の解の収束性も良好である.
(3) 薄い地層のモデル化については, 薄い地層を含 むボクセルの透水係数を直交異方性の等価透水係 数に換算する方法を提案した. 薄い地層の透水性 が周辺地盤より大きい場合は, 精度よく計算でき ることが確認できた. 薄い地層の透水性が周辺よ り小さい場合も, 概ね妥当な結果が得られている が, さらなる検討の余地があると考える.

(4) 地下施設の通過流量については, 施設の透水性 が周辺地盤より大きい場合は, 精度よく計算でき ることが確認できた. 施設の透水性が周辺より小 さい場合は, 施設に沿うような流れ場となるため, 地下施設の表面積の近似が悪くなる曲面形状の施 設では通過流量が多めに計算される. ただし, 同 じ物差しによる相対比較という観点での施設位置 の検討は可能なので, メッシュ作成が楽になるメ リットは大いに活かせる.

本システムの開発の目的は, 大幅なメッシュ変更 を繰り返す地下施設位置のケーススタディなど, 地 下施設を計画する上で, 従来型のFEMでは困難だっ た検討を可能にすることである. つまり, 従来型の FEMに完全に代わるシステムの開発が目的ではない. 解析による検討を諦めていた問題が, 少々精度が劣 っても解析で検討できるようになったことが重要で ある. ボクセル解析によるケーススタディの結果, 注目すべきいくつかのケースに対しては, 解析精度 の向上を図るためや, 飽和・不飽和解析による地下 水面の検討を行うために, 従来型のFEMも, むしろ 積極的に利用することが現実的であると考える. 著 者らの経験では, 地盤の不飽和特性や, 降水涵養量 に関するデータが, 比較的充実している場合でさえ も, 飽和・不飽和解析で求められた地下水面と実際 の地下水面を一致させるのは難しく, 植生等の違い による涵養量の分布や，地盤の透水性とその分布の バラツキ等を詳細に検討しなければならない. 地下 施設計画において, 地下施設の存在が地下水面に及 ぼす影響は非常に重要であり, 飽和・不飽和解析に よる検討は間違いなく必要であろうが, 地質調査の 進展に伴う地質構造の修正に迅速に対応し, 地下水 解析を行って, 以降の調査計画に反映させたり, 地 下施設の位置や形態の検討を十分に行ったりする上 で, 地質調査で推定された地下水面を境界条件とし た解析を並行して実施することは現実的なアプロー チであると考える. ここでのボクセル解析システム はその検討を対象として開発したものである.

したがって, 今後の開発計画にも飽和・不飽和解 析機能の追加は予定していない. 地下施設通過流量 の計算精度の向上の工夫, および, 八分岐法（ボク 
セルを八つに分け $1 / 2$ の大きさにする方法）により 部分的に細かいボクセルで分割を可能にすることを 課題として考えている.

\section{参考文献}

1) 核燃料サイクル開発機構: わが国における高レベル放 射性廃棄物地首処分の技術的信頼性一地首処分研究 開発第2次とりまとめ一分冊 2 地層処分の工学的技 術, JNC TN1400 99-022, 1999.

2）核燃料サイクル開発機構: 地首処分場のレイアウトに 関する検討，JNC TN8400 99-044, 1999.

3) Requicha, A.A.G. and Voelcker, H.B.: Solid Modeling: A historical summary and contemporary assessment, IEEE Comput. Graphics and Appl., Vol.2, No.2, pp. 9-24, Mar.1982.

4）鈴木克幸: メッシュレス解析法・ボクセル解析法の動 向, 第3回日本計算工学会講習会教材 自動メッシュ 生成の基礎と応用, pp. 55-62, 1998.

5) 谷口健男: 構造解析のための自動メッシュ生成-3次元 領域を対象とした場合-, 第3回日本計算工学会講習会 教材 自動メッシュ生成の基礎と応用, pp. 1-10, 1998.

6) Taniguchi, T. and Fillion, E.: Numerical experiments for 3dimensional flow analysis in a fractured rock with porous matrix, Advances in Water Resources, Vol.19, No.2, pp. 97-107, 1996.

7) Belytschko, T., Krongauz, Y., Organ, D., Fleming, M. and Krysl, P.: Meshless methods: An overview and recent developments, Comput. Methods in Appl. Mech. Engrg., Vol.139, pp. 3-47, 1996.

8）鈴木克幸, 寺田賢二郎, 大坪英臣, 米里直樹 : ボクセ ル情報を用いたりリッド構造の解析法, 日本造船学 会論文集, Vol.182, pp.595-600, 1997.

9) Monaghan, J.J.: An introduction to SPH, Comput. Phys. Comm, Vol.48, pp. 89-96, 1988.

10) Babuska, $I$ and Menlenk, J.M.: The partition of unity finite element method, Int. J. Numer. Methods Engrg., Vol.40, pp. 727-758, 1997.

11) Belytschko, T., Lu, Y.Y. and Gu, L.: Element-free Galerkin methods, Int. J. Numer. Methods Engrg., Vol.37, pp. 229256, 1994.

12) Fleming, M., Chu, Y.A. and Belytschko, T.: Enriched Element-free Galerkin methods for crack tip fields, Int. J. Numer. Methods Engrg., Vol.40, pp. 1483-1504, 1997.

13) Krysl, P. and Belytschko, T.: The element free Galerkin method for dynamic propagation of arbitrary 3-D cracks, Int. J. Numer. Methods Engrg., Vol.44, pp. 767-800, 1999.

14) Barry, W. and Saigal, S. : A three-dimensional element-free
Galerkin elastic and elastoplastic formulation, Int. J. Numer. Methods Engrg., Vol.46, pp. 641-693, 1999.

15) 若土耕一, 奥田洋司: 3次元CAD援用EFGMの開発, 計 算工学講演会論文集, Vol.5, pp. 231-232, 2000.

16) 櫻井英行: エレメント・フリー・ガラーキン法を用い た三次元地下水流動解析システムの開発, 計算工学 講演会論文集, Vol.3,pp. 341-344, 1998.

17) Hollister, S.J. and Kikuchi, N.: Homogenization theory and digital imaging: a basis for studying the mechanics and design principles of bone tissue, Biotech. and Bioengrg., Vol.43, No.7, pp. 586-596, 1994.

18) 鳥垣俊和, 藤谷克郎, 富田直幸: ボクセルモテルを用 いた構造解析における接触問題の取り扱い, 計算工 学講演会論文集, Vol.3, pp. 369-372, 1998.

19) Kikuchi, N. and Diaz, A.: 第13回Quintセミナーテキスト, （株）くいんと, 1997.

20) 菊池昇, 関口美奈子, 横田政幸, 石井恵三, スコッ ト・ホリスター: CAEにおける最適設計法の発展とそ の未来: CAEは生き残るために何を目指すのか?，第 3回最適化シンポジウム講演論文集, pp.183-194, 1998.

21）鈴木克幸, 寺田賢二郎, 大坪英臣, 米里直樹: 多重ボ クセル情報を用いたソリッド構造の解析法, 計算工 学講演会論文集, Vol.2, pp. 395-398, 1997.

22) 鈴木克幸, 大坪英臣, 閔勝載, 上杉忠輝: 境界適合ボ クセル要素の開発とその汎用有限要素コードへの組 み込み, 計算工学講演会論文集, Vol.3, pp. 373-376, 1998.

23) 桜井英行, 難波治之, 古賀小枝子, 古宇田亮一, 升本 畺二, 原田芳金: 汎用ソリッド・モデラを用いた深成 岩地域と火山岩地域の3次元地質構造可視画像化, 地 質ニュース, No.502, pp. 36-41, 1996.

24) 桜井英行, 難波治之, 後藤高志, 古宇田亮一, 河野 愛: 地質構造の三次元モテリングと可視化, 計算工学 講演会論文集, Vol.2, pp. 503-506, 1997.

25) 桜井英行, 後藤高志, 古宇田亮一, 田代寿春, 宮島繁, 中井仁彦: 長期地質変動予測手法の開発（その 5 ）地質情報の可視化一, 土木学会第55回年次講演会論 文集, CS-117, 2000.

26) MAtheron, G.: Principle of geostatistics, Economic Geology 58, pp. 1246-1266, 1963.

27) 鈴木誠, 石井清, 黒田英高: 3次元地質構造の推定と画 像出力, 清水建設研究報告, 第48号, pp. 79-85, 1988.

28) 河西基, 田中靖治, 五十嵐敏文: 高レベル放射性廃棄 物地層処分の天然バリア性能評価手法の開発一割れ 目系岩盤中の地下水流動解析手法一, 電力中央研究 所報告, U93054, pp. 1-46, 1994.

(2000. 9. 11 受付) 


\section{VOXEL ANALYSIS OF GROUNDWATER FLOW \\ FOR UNDERGROUND REPOSITORY PLANNING}

\section{Hideyuki SAKURAI and Tomonari SHIRAISHI}

As one of the system useful for planning underground repositories, such as radioactive waste disposal facilities, we develop a groundwater flow analysis system using the voxel analysis method. This paper shows an example of issues of mesh generation in the groundwater flow analysis using the conventional finite element method. Use of the voxel analysis method solves the issues and improves the analysis efficiency. The paper also discusses an influence of the voxel mesh with jaggy surface upon the accuracy of analysis results. 